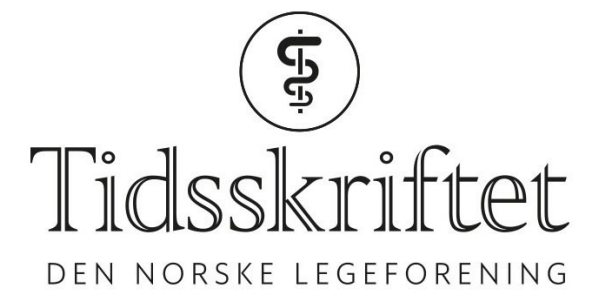

\title{
Er pasientene tjent med Norsk pasientskadeerstatning?
}

DEBATT

\section{DAG BRATLID}

E-post: bratlid@vikenfiber.no

Dag Bratlid (f. 1944) er tidligere professor fra Norges teknisk-naturvitenskapelige universitet og tidligere overlege ved Barne- og ungdomsklinikken, St. Olavs hospital, og har en mastergrad i helseadministrasjon fra 2001. Han har over 30 års erfaring som sakkyndig for Norsk pasientskadeerstatning, og var fast intern sakkyndig 2011-16.

Forfatter har fylt ut ICMJE-skjemaet og oppgir ingen interessekonflikter.

Gjennom reportasjer i NRK Dagsrevyen har Norsk pasientskadeerstatning og Pasientskadenemnda vært utsatt for hard kritikk fra både pasienter og advokater, men også fra tidligere og nåværende legesakkyndige i ordningene. Reportasjene har ført til en betydelig medieinteresse. Korte og redigerte TV-reportasjer og debattinnlegg gir imidlertid ikke en god nok forståelse av hva kritikken bunner i, og i hvilken grad den er berettiget.

Norsk pasientskadeerstatning (NPE) er en statlig etat under Helse- og omsorgsdepartementet som behandler klager på feilbehandling i den offentlige og private helsetjenesten, i tillegg til tannhelsetjenesten. Dyktige saksbehandlere samler inn alle journaler og dokumentasjon med betydning for vurdering av klagen. Deretter vurderer saksbehandlerne hvilket fagområde klagen hører inn under. En lege med spesiell kompetanse innen dette fagområdet blir så gitt i oppdrag å vurdere klagen. Etter en gjennomgang av saksdokumentene skriver den sakkyndige en erklæring. Erklæringen blir så oversendt til pasienten og behandlingsstedet for kommentarer, før det fattes et vedtak.

De aller fleste pasienter er tjent med denne delen av ordningen. Uten slik bistand ville det for mange vært vanskelig å fremme et krav på annet grunnlag enn sin egen følelse av feilbehandling. Hele saksbehandlingen hos Norsk pasientskadeerstatning er dessuten gratis.

\section{Sakkyndig vurdering av klage}

Det er en omfattende oppgave for en sakkyndig å gjennomgå pasientjournalene og de bildediagnostiske undersøkelsene. I de fleste saker er det tilstrekkelig med én sakkyndig for å vurdere behandlingen, men i noen saker trengs det flere sakkyndige for å vurdere behandlingen i ulike deler av sykdomsforløpet. I slike tilfeller har Norsk pasientskadeerstatning som prinsipp at hver sakkyndig kun skal vurdere det fagområdet vedkommende er spesialist i. En spesialist i allmennmedisin vurderer behandlingen hos fastlegen, en spesialist i indremedisin vurderer den medisinske behandlingen, mens en kirurg vurderer den kirurgiske behandlingen osv. 
Den sakkyndige skal vurdere om behandlingen har vært i tråd med god medisinsk praksis. Dersom det foreligger behandlingssvikt, skal vedkommende deretter vurdere om det er mer enn 50 \% sannsynlighet for en årsakssammenheng mellom behandlingssvikten og pasientens skade. Begge disse vurderingene bygger på den sakkyndiges skjønn og er altså ikke nødvendigvis en objektiv vurdering.

\section{Hvilke avvik skal dokumenteres?}

Når en pasient klager på et behandlingsforløp, har pasienten krav på at alle små og store avvik fra det normale behandlingsforløpet skal påpekes i den sakkyndiges erklæring. På de halvårlige møtene for de interne sakkyndige og ledelsen (Fellesforum) blir det imidlertid innskjerpet at sakkyndig skal konsentrere seg om de forhold/avvik som kan ha betydning for skaden.

Fordi dette imidlertid er skjønnsmessige vurderinger, er det etter min mening viktig at alle større og mindre avvik i behandlingsforløpet blir påpekt. Dersom et behandlingsforløp, i tillegg til å ha en større svikt, også er preget av en rekke andre avvik fra god medisinsk praksis, kan det tyde på et behandlingsforløp med generelt lav kvalitet. Alle avvik fra god medisinsk praksis bør derfor tas med i erklæringen, ikke minst av hensyn til pasienten.

\section{Uenighet mellom sakkyndige}

Medisinsk behandling er i våre dager ikke så spesialisert som man skulle tro, slik bl.a. professor Geir Hoff peker på (1). Pasientbehandlingen blir ofte styrt av retningslinjer som journalforskrifter, veiledere, strukturerte pakkeforløp og lignende. De fleste leger kan derfor i stor grad vurdere om god medisinsk praksis er fulgt, også innen andre spesialiteter enn ens egen. En kirurg kan av den grunn vurdere om fastlegen utredet pasienten godt nok og henviste tidsnok, og om anestesilegene hadde god nok kontroll med pasientens blodtrykk og surstoffmetning under operasjonen, for å nevne noen eksempler.

Flere studier har vist at nettopp brudd på generelle medisinske behandlingsrutiner og allmenne veiledere ofte er årsaker til medisinsk feilbehandling $(2,3)$. Hvis slike avvik ikke påpekes, kan det medføre at pasienten ikke får den erstatningen vedkommende har krav på, eller først får erstatning ved å ta saken til rettsapparatet der andre sakkyndige kan bidra i vurderingen.

I sak 2013/01876 vedrørende fødselsskade fant jeg som barnelege flere klare avvik i behandlingsforløpet som den sakkyndige spesialisten hadde oversett. Siden jeg ikke hadde formell kompetanse til å vurdere dette, ble jeg imidlertid av nærmeste leder og den sakkyndige spesialisten bedt om å endre min erklæring på disse punktene, noe jeg av profesjonsetiske grunner ikke kunne gjøre.

I et annet tilfelle av slik uenighet fant imidlertid den sakkyndige uten den formelle spesialitetskompetansen til slutt å måtte gi seg. Den faglige uenigheten mellom spesialistene fremkom derfor ikke i erklæringen, og pasienten fikk dermed heller ikke kjennskap til dette forholdet.

At slike vurderinger fra andre kolleger uten formell kompetanse kan ha avgjørende betydning, illustreres av en annen sak (2007/01186) som gjaldt en alvorlig behandlingsskade. Klagen var, på grunnlag av sakkyndig vurdering av spesialister innen to ulike spesialiteter, avvist av både Norsk pasientskadeerstatning og Pasientskadenemnda. I forbindelse med at Pasientskadenemnda ble stevnet for denne avgjørelsen, ba en advokat meg om å vurdere saken som partsoppnevnt sakkyndig. Jeg fant da (som barnelege) at det forelå vesentlig og alvorlig svikt i behandlingsforløpet innen begge disse spesialitetene. Da min erklæring gjennom prosesskriftet til retten ble kjent for Pasientskadenemnda, besluttet man å ta saken opp til ny behandling, og stevningen ble trukket tilbake.

Sakene understreker at en generelt kompetent legespesialist absolutt kan gi vurderinger av behandlingsforløpet i andre spesialiteter. Slike vurderinger vil også kunne være en motvekt 
mot laugsmentaliteten om (helst) ikke å kritisere kolleger, som nok gjør seg gjeldende innenfor mange spesialiteter. Det er derfor vanskelig å forstå hvorfor Norsk pasientskadeerstatning så sterkt fastholder en silotenkning vedrørende kompetanse som ikke hører hjemme i moderne medisin.

\section{Hvor viktig er de sakkyndige?}

Norsk pasientskadeerstatning peker på at det er feil i NRKs reportasjer når det hevdes at det er de sakkyndige som avgjør sakene (4). Det vises til at også andre opplysninger utgjør et viktig grunnlag for avgjørelsen, som uttalelser fra behandlingsstedet, annen dokumentasjon og pasientens egne beskrivelser. Erklæringene må i tillegg vurderes opp mot lovverket, og dette er det ikke de sakkyndige som gjør.

Dette kan illustreres ved sak 2012/03173 som gjaldt forsinket diagnostikk og behandling. Saken har gjennom flere år medført en belastende lojalitetskonflikt mellom Norsk pasientskadeerstatning som min oppdragsgiver, og mine egne profesjonsetiske forpliktelser. Klagen ble opprinnelig avvist av Norsk pasientskadeerstatning fordi man mente at klagen hadde kommet for sent og at saken derfor juridisk sett var foreldet. Ved en administrativ feil ble jeg imidlertid bedt om å gi en sakkyndig vurdering av klagen. Jeg konkluderte med at pasienten var blitt utsatt for feilbehandling og ansvarsfraskrivelse fra helsevesenet i en grad jeg aldri tidligere hadde opplevd.

Overraskelsen var stor da jeg fikk beskjed om at siden saken var avvist på juridisk grunnlag, skulle det ikke vært foretatt noen sakkyndig vurdering. Klagen ville derfor ikke bli behandlet av Norsk pasientskadeerstatning, og min erklæring ville heller ikke bli gjort kjent. Etter gjentatte påtrykk fra meg har Norsk pasientskadeerstatning nå, over tre år etter at erklæringen ble skrevet, likevel valgt å sende den over til de involverte. Det er uforståelig at Norsk pasientskadeerstatning kan avgjøre om en sak er foreldet uten at det har vært medisinsk kompetanse med i vurderingen.

\section{Part i saksbehandlingen?}

Både pasienter og helsepersonell har fremholdt at pasientskadeordningene synes å ha en egeninteresse av at pasientklagene helst ikke skal føre frem (5). Norsk pasientskadeerstatning avviser imidlertid konsekvent at pasienter har fått avslag på ufullstendig grunnlag $(4,6)$. Det vises også til at kun $10 \%$ av sakene som blir påklaget til Pasientskadenemnda, blir omgjort (4). De glemmer da at flere saker ankes videre til retten og vinnes der. Svært mange av de sakene som (omsider) blir vunnet av pasienten $\mathrm{i}$ tingretten, ankes imidlertid videre av Pasientskadenemnda.

Spørsmålet om behandlingssvikt og årsakssammenheng med skade er imidlertid en skjønnsmessig medisinsk vurdering, som forskjellige sakkyndige kan vurdere ulikt - slik er den medisinske hverdagen. Det er derfor helt uforståelig at man finner grunn til å anke en rettsavgjørelse der dommerne, ut fra en totalvurdering av ulike juridiske og medisinske argumenter, har konkludert med at pasienten har krav på erstatning. Det har også nylig vært en sak der Pasientskadenemnda anket en rettsavgjørelse som gikk dem imot, helt til Høyesterett, og også tapte der (7).

Når en sak om medisinsk feilbehandling ankes helt til Høyesterett, er antagelig motivet for anken i større grad basert på hensynet til juridisk prestisje enn hensynet til en objektiv vurdering av årsakssammenhengen mellom behandlingssvikt og pasientskade. Ille er det uansett.

\section{Ledelse uten medisinsk kompetanse}

Selv om mange forhold ved Norsk pasientskadeerstatning og Pasientskadenemnda kan kritiseres, tror jeg at de fleste pasienter og helsevesenet skal være glade for at vi har denne ordningen i Norge. Selv om det er en rekke forhold ved virksomheten som kan forbedres, er 
jeg ikke enig i at Norsk pasientskadeerstatning fremstår som en maktarrogant bastion (8, 9).

Det synes imidlertid å være en høy terskel for å ta saklig kritikk alvorlig, og den interne justisen er streng. Dyktige sakkyndige som fremmer saklig kritikk internt, eller som sakkyndige i retten bidrar til at pasienter får medhold etter å ha fått avslag både i Norsk pasientskadeerstatning og Pasientskadenemnda, blir ofte marginalisert eller fjernet. Den nevnte silotenkningen i vurderingen av sakkyndiges kompetanse hører heller ikke hjemme i moderne medisin og gagner verken organisasjonene selv eller pasientene.

Antagelig kan flere av disse forholdene forklares ved fravær av medisinsk kompetanse i den sentrale ledelsen, noe som medfører at juridiske forhold som formell kompetanse og lovverk ofte blir vektlagt fremfor medisinske problemstillinger. Det burde vært en selvfølge at det i denne organisasjonen var en bred medisinsk kompetanse i den sentrale ledelsen.

\section{LITTERATUR:}

1. Hoff G. Pasientskadeordningen - en god idé med sviktende praksis. Aftenposten del 2, 6.4.2017. https://www.aftenposten.no/meninger/debatt/i/dAyQA/Kort-sagt_-6-april (24.10.2017).

2. Berglund S. "Every case of asphyxia can be used as a learning example". Conclusions from an analysis of substandard obstetrical care. J Perinat Med 2011; 40: 9 - 18. [PubMed]

3. Andreasen S, Backe B, Øian P. Claims for compensation after alleged birth asphyxia: a nationwide study covering 15 years. Acta Obstet Gynecol Scand 2014; 93: 152 - 8. [PubMed][CrossRef]

4. Norsk pasientskadeerstatning. Feil fremstilling av NPEs bruk av sakkyndige. 29.3.2017.

https://www.npe.no/no/Om-NPE/aktuelt/Feil-fremstilling-av-NPEs-bruk-av-sakkyndige/ (24.10.2017).

5. Dagsrevyen NRK. 28.3.2017 kl. 19 og kl. 21.

https://tv.nrk.no/serie/dagsrevyen/nnfa19032817/28-03-2017\#t=6m51S (24.10.2017).

6. Christiansen R-M. Pasientene skal få den erstatning de har krav på. Aftenposten del 2, 2.4.2017. https://www.aftenposten.no/meninger/debatt/i/oa1no/Kort-sagt_-sondag-2-april (24.10.2017).

7. Norges høyesterett. Høyesteretts dom HR-2015-02265-A, 12. november 2015. https://www.domstol.no/globalassets/upload/hret/avgjorelser/2015/avdeling-avgjorelser-novembe-201 5/sak-2015-596-anonymisert.pdf(24.10.2017).

8. Jørstad RG. Pasientskadeerstatningen er ikke maktarrogant. Aftenposten del 2, 2.4.2017. https://www.aftenposten.no/meninger/debatt/i/oa1no/Kort-sagt_-sondag-2-april (24.10.2017).

9. Hoff G. Pasientskadeordningen er en maktarrogant bastion. Aftenposten del 2, 30.3.2017. https://www.aftenposten.no/meninger/debatt/i/dAAzO/-Pasientskadeordningen-er-en-maktarrogant-b astion-Geir-Hoff(24.10.2017).

Publisert: 12. desember 2017. Tidsskr Nor Legeforen. DOI:10.4045/tidsskr.17.0340

(C) Tidsskrift for Den norske legeforening 2020. Lastet ned fra tidsskriftet.no 